\title{
Effect Of Third Party Funds On Lending To National Private Commercial Banks
}

\author{
Didin Rasyidin Wahyu ${ }^{1 *}$, Herna Setiawati ${ }^{2}$ \\ Bina Bangsa University ${ }^{1 *}, 2$ \\ Corresponding Author: didinrw.28@gmail.com ${ }^{1 *}$
}

Keywords : Demand Deposits, Savings, Deposits, Credit Distribution

\begin{abstract}
This study aims to determine whether there is an influence between the independent variables (Current Accounts, Savings, and Deposits) on the dependent variable (Credit Distribution) at the National Private Commercial Banks listed on the Indonesia Stock Exchange (IDX) for the period 2014-2019. The research method used in this study is a quantitative method, the sample used in this study is a national private public banking company, a total of 7 national private banking companies are determined as a sample, the sampling technique is done using the Purposive Sampling method . The data used are secondary data in the form of company financial statements, analysis using Multiple Linear Regression analysis. The results showed that partially there is an influence of Demand Deposits on Credit Distribution, there is an effect of Savings on Credit Distribution and there is an influence of Deposits on Credit Distribution. While simultaneously (together) there is the influence of Demand Deposits, Savings, and Deposits on Credit Distribution. there is an effect of Savings on Credit Distribution and there is an influence of Deposits on Credit Distribution. While simultaneously (together) there is the influence of Demand Deposits, Savings, and Deposits on Credit Distribution. there is an effect of Savings on Credit Distribution and there is an influence of Deposits on Credit Distribution. While simultaneously (together) there is the influence of Demand Deposits, Savings, and Deposits on Credit Distribution.
\end{abstract}




\section{Introduction}

The world of banking as a financial and regulatory institution will always compete to gain the trust of the public and entrepreneurs who own capital to channel their funds to those in need. Therefore, the government always tries to revive and improve the banking world through various policy packages in the form of deregulation packages, especially those relating to the banking sector. Basically the essence of all existing policies is to give freedom to the banking world in its efforts to collect funds from the public and then channel them back to the community.

The community or company as the owner of the funds has a desire, so that the existing funds can grow. The increase in the value of a fund is a development desired by the owners of the funds both in the short term and for the future.

Banks themselves generally require additional funds from various parties, including from customers which can be used as a source of funds in the form of deposits, or better known as checking accounts, savings and time deposits. In carrying out these activities, customers will consider the benefits and convenience factors obtained in choosing the type of deposit to be selected.

The average GIRO in several banking companies consisting of Bank Rakyat Indonesia Agroniaga, Tbk. (AGRO), Bank Cimbi Niaga, Tbk. (BNGA), Bank Mega, Tbk. (MEGA), Bank OCBC NISP, Tbk. (NISP), Bank Permata, Tbk. (BNLI), Bank Danamon Indonesia, Tbk. (BDMN), and Bank Maybank, Tbk. (BNII). it can be seen every year, from 2014 to 2019 it has increased, the biggest increase occurred in 2018 which was298,611,057from the previous year. However, in 2019 there was another decline of 296,194,570,Meanwhile, the lowest average decline occurred in 2014 which was66,788,737from the previous year. the average SAVINGS in several banking companies consisting of Bank Rakyat Indonesia Agroniaga, Tbk. (AGRO), Bank Cimbi Niaga, Tbk. (BNGA), Bank Mega, Tbk. (MEGA), Bank OCBC NISP, Tbk. (NISP), Bank Permata, Tbk. (BNLI), Bank Danamon Indonesia, Tbk. (BDMN), and Bank Maybank, Tbk. (BNII), it can be seen that every year the average number of Savings at National Private Commercial banks tends to increase from 2014 which is equal to64.077.111and in 2019 the average amount of savings reached182,588,139.the average DEPOSIT in several banking companies consisting of Bank Rakyat Indonesia Agroniaga, Tbk. (AGRO), Bank Cimbi Niaga, Tbk. (BNGA), Bank Mega, Tbk. (MEGA), Bank OCBC NISP, Tbk. (NISP), Bank Permata, Tbk. (BNLI), Bank Danamon Indonesia, Tbk. (BDMN), and Bank Maybank, Tbk. (BNII). It can be seen that the trend of increasing the average number of deposits in 2014 to 2019 continued to increase, namely by703.9355.762up to you2,644,921,317.average CREDIT DISTRIBUTION in several banking companies consisting of Bank Rakyat Indonesia Agroniaga, Tbk. (AGRO), Bank Cimbi Niaga, Tbk. (BNGA), Bank Mega, Tbk. (MEGA), Bank OCBC NISP, Tbk. (NISP), Bank Permata, Tbk. (BNLI), Bank Danamon Indonesia, Tbk. (BDMN), and Bank Maybank, Tbk. (BNII). it can be seen that in 2014-2019 it continued to increase from the average number of Credit Distributions of 745,549,612until it reaches the average number of Credit Distributions in 2019 of 2,748,463,847.

Based on research conducted by Andi Widiawati (2018)who said that there was a positive influence of Current Accounts on Credit Distribution, while research conducted by Anita Sari (2017) which said that there was a positive influence of Savings on Credit Distribution, Deposits had an effect on Credit Distribution. This research was conducted by Lailatul Mukaromah and Ida Bagus Badjra (2015). Princess Andini,Leny Suzan, and Dewa PK, Mahardika (2016) states that Current Accounts, Savings, Time Deposits together have a significant effect on Credit Distribution. 


\section{Research Method}

The research method used is quantitative method, namely data in the form of numbers or numbers used to examine certain populations or samples, sampling techniques are carried out randomly, data collection uses research instruments, data analysis is quantitative/statistical with the aim of testing hypotheses that have been established. (Sugiyono, 2017) It is said that descriptive quantitative research is research conducted to determine the value of independent variables, either one or more (independent) variables without making comparisons, or connecting with other variables (Sugiyono, 2017).

This study aims to provide empirical evidence regarding the effect of Current Accounts, Savings and Time Deposits on Credit Distribution. This study uses secondary data, namely data in the form of annual financial documents/reports of national private commercial banks listed on the IDX for the period 2014-2019 which is written data relating to the object of research published by companies and the Indonesia Stock Exchange.

The population of this study are all national private public banking companies listed on the Indonesia Stock Exchange, amounting to 34 companies and. Sampling of 7 private public banking companies was carried out using a non-probability sample design with a purposive sampling method with the criteria of a certain consideration.

Data collection techniqueln this study, researchers used a documentation technique based on financial reports, annual reports published by pharmaceutical companies through the www.idx.co.id site published in 2014-2019.. The data used is annual data that has been published to the general public in the form of financial reports and annual reports.

Data analysis technique is a form of application of a method in processing the data obtained previously to get a conclusion. This study uses SPSS 16 for Windows as an intermediary in conducting data analysis.

\section{Results and Discussion}

Before performing linear regression analysis for hypothesis testing, the validity of the regression equation was first tested based on the classical assumption test. Theoretically, the model used will produce a valid estimator parameter value if it meets the normality assumption, there is no heteroscedasticity, no multicollinearity, and no autocollinearity. Classical assumption testing is done with the help of IBM SPSS Statistics 16.0 software.

\section{a) Normality Test Results}

The normality test aims to test the hypothesis, whether the regression model, whether the dependent variable and the independent variable both have a normal distribution or not. A good regression model is one that has a normal distribution. The testing tool used by the author is the Kolmogrov Smirnov test. In this case, to find out whether the residual distribution is normally distributed if the significance value is more than 0.05 . 
Table 1. Normality test

\begin{tabular}{llr}
\hline & One-Sample Kolmogorov-Smirnov Test \\
Unstandardized Residual & \\
\hline Normal Parameters & & .0000000 \\
& mean & .13882826 \\
& Std. & \\
Most Extreme Differences & Deviation & Absolute \\
& Positive & .118 \\
Kolmogorov-Smirnov Z & negative & .080 \\
asymp. Sig. (2-tailed) & & -.118 \\
a. Test distribution is Normal. & & .763 \\
\hline Data processed by SPSS 16.0 & .606 \\
\hline
\end{tabular}

Data processed by SPSS 16.0

Based on table 1 above, it can be seen that the probability of kolmogrov - smirnov is 0.763 and Asymp. The sig of 0.606 is greater than 0.05 , so it can be concluded that the data used has met the assumption of normality.

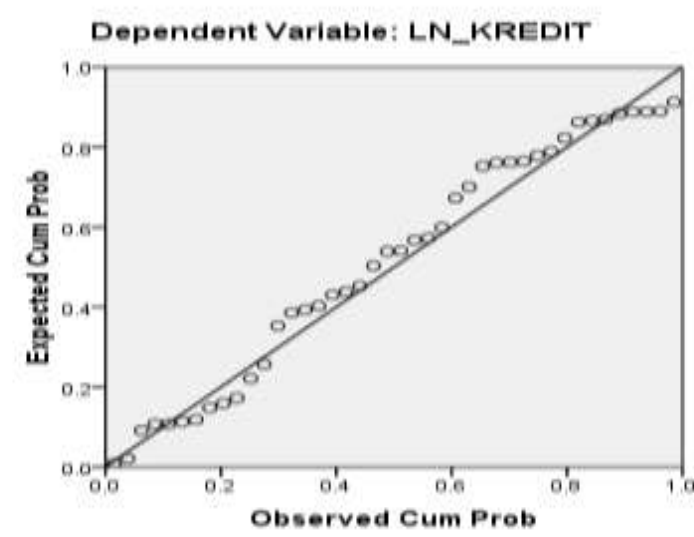

Figure 1. Normal PP Plot

If the residuals come from a normal distribution, then the values of the data distribution will lie around a straight line. From the plot above, it can be seen that the points are spread out following a linear line so that it can be said that the normality requirements are met.

\section{b) Heteroscedasticity Test Results}

The heteroscedasticity test is used to determine whether or not there is a deviation from the classical assumption of heteroscedasticity, namely the presence of unequal variance from the residuals for all observations in the regression model. The prerequisite that must be met in the regression model is the absence of heteroscedasticity symptoms.

In this study, the author uses the method of looking at the pattern of dots in regression scatterplots, this method is by looking at the scatterplot graph between the standardized predicted value (ZPRED) and the studentized residual (SRESID). whether or not there is a certain pattern in the scatterplot graph between SRESID and ZPRED where the $Y$ axis is the predicted $Y$ and the $X$ axis is the residual ( $Y$ predicted $-Y$ actually). The basis for decision making are:

- If there is a certain pattern, such as the existing dots forming a certain regular pattern (wavy, 
widening and then narrowing), then heteroscedasticity occurs.

- If there is no clear pattern, such as the dots spread above and below the number 0 on the $Y$ axis, then there is no heteroscedasticity.

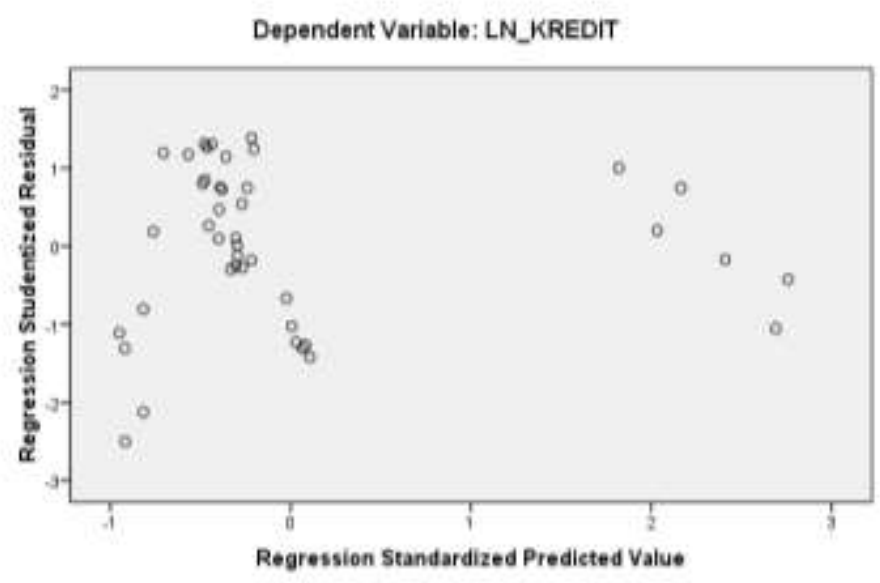

Figure 2. Scatterplot

Based on Figure 2 above, it can be seen that the dots do not form a clear pattern, and the points spread above and below the zero (0) on the $Y$ axis. So it can be concluded that there is no heteroscedasticity problem in the regression model.

\section{c) Multicollinearity test results}

Multicollinearity test is a condition where the regression model found a perfect or near perfect correlation between the independent variables. In a good regression model, there should not be a perfect or near perfect correlation between the independent variables (the correlation is 1 or close to 1 ). To find out a regression model free from multicollinearity, namely the VIF (Variance Inflation Factor) value of less than 10 and having a tolerance number of more than 0.1, the following table presents the multicollinearity test.

Table 2. Multicollinearity test

\begin{tabular}{llll}
\hline \multicolumn{3}{c}{ Collinearity Statistics } \\
Model & Tolerance & VIF \\
\hline 1 LN_GIRO & .189 & 5,292 \\
& LN_SAVINGS & .440 & 2.273 \\
& LN_DEPOSIT & .248 & 4.037 \\
a. Dependent Variable: LN_CREDIT & & \\
\hline
\end{tabular}

Source: Data processed SPSS 16.0

Based on table 2 above, it is known that the tolerance value is greater than 0.10 and the VIF value of the three independent variables is less than 10 . So it can be concluded that there is no multicollinearity between the independent variables. 


\section{d) Autocorrelation Test}

The autocorrelation test aims to find out whether there is a correlation between the confounding errors in the observation data during other observations in the linear regression model. A good regression model is one in which there is no correlation.

In this study, the researchers tested the Durbin-Watson by comparing the results of the DW table. If DW statistic > DW table, it can be concluded that there is no autocorrelation problem.

Table 3 .Decision Autocorrelation

\begin{tabular}{cc}
\hline DW value & Description \\
DW below -2 & There is a Positive Autocorrelation \\
DW between $-2,+2$ & No Autocorrelation \\
DW above -2 & There is a negative autocorrelation \\
\hline
\end{tabular}

Source: Data processed SPSS 16.0

Table 4 autocorrelation test

\begin{tabular}{|c|c|c|c|c|c|}
\hline \multicolumn{6}{|c|}{ Model Summaryb } \\
\hline Model & $\mathrm{R}$ & R Square & $\begin{array}{l}\text { Adjusted R } \\
\text { Square }\end{array}$ & $\begin{array}{l}\text { Std. Error of the } \\
\text { Estimate }\end{array}$ & Durbin-Watson \\
\hline 1 & $.997 a$ & .993 & .993 & .14420 & .593 \\
\hline \multicolumn{6}{|c|}{ a. Predictors: (Constant), LN_DEPOSITO, LN_GIRO, LN_TABUNGAN } \\
\hline \multicolumn{6}{|c|}{ b. Dependent Variable: LN_CREDIT } \\
\hline
\end{tabular}

Table 4 shows that the Durbin-Watson (DW) value is 0.593 which will be compared with the value in the DW table using a significance level of 0.05 . The DW value according to the table with the number of samples $42(n)$ and the number of independent variables $3(k)$ is $D L=1.3573$ and $\mathrm{DU}=1.6617$. So the value of $3-\mathrm{DL}=3-1.3573=1.6427$ and the value of $3-\mathrm{DU}=3-1.6617=1.3383$. Therefore the value of $D W=0.593$. That the $D W$ value lies between -2 to +2 , so the conclusion obtained for this model is that there is no autocorrelation, namely there is no correlation between the residuals in one observation and other observations in the regression model.

\section{e) Multiple Linear Regression Analysis}

Multiple linear regression analysis is used to find out how the relationship between two or more variables, in this case the variables of Current Accounts, Savings, and Time Deposits on Credit Distribution. Based on the processing results obtained a regression equation that relates each independent variable to credit distribution as presented in the following table: 
Table 5 multiple linear regression

\begin{tabular}{lcccccc}
\hline \multicolumn{7}{c}{ Coefficientsa } \\
& \multicolumn{2}{c}{$\begin{array}{c}\text { Standardize } \\
\text { Unstandardized } \\
\text { Coefficients }\end{array}$} & \multicolumn{2}{c}{$\begin{array}{c}\text { d } \\
\text { Coefficients }\end{array}$} \\
Model & B & Std. Error & Beta & T & Sig. \\
\hline 1 (Constant) & $-1,247$ & .406 & & -3.071 & .004 \\
LN_GIRO & .221 & .059 & .200 & 3,731 & .001 \\
LN_SAVINGS & .509 & .074 & .374 & 6.891 & .000 \\
LN_DEPOSIT & .407 & .048 & .436 & 8,526 & .000 \\
a. Dependent Variable: LN_CREDIT & & & & \\
\hline Source: Dataprocessed SPSS 16.0 & & & & &
\end{tabular}

Based on table 5 above, it can be concluded that the multiple regression equation is:

$$
Y=-1.247+(221)(X 1)+(509)(X 2)+(407)(X 3)+e
$$

Based on the predicted value, it can be drawn the regression coefficient of each variable as follows:

1. The constant value (a) is $-1,247$. This number shows the level of credit obtained by the bank, if the level of Current Accounts, Savings, Deposits decreases, the level of lending to the Bank is negative.

2. The regression coefficient for the current account variable (X1) is 221 , this shows that the current account variable increases by one unit with a positive sign, then the credit variable will increase by 221.

3. The regression coefficient for the Savings variable (X2) is 509 , this shows that the Savings variable increases by one unit with a positive sign, then the Credit variable will increase by 509.

4. The regression coefficient for the Time Deposit variable (X3) is 407 , this shows that the Time Deposit variable increases by one unit with a positive sign, then the Credit variable will increase by 407.

\section{f) Determination Test}

The coefficient of determination is a value that states the simultaneous influence of the independent variable on the dependent variable. In the problem being researched, namely the influence of Current Accounts, Savings and Time Deposits on Credit Distribution, the coefficient of multiple determination is obtained as follows:

Table 6 Interpretation of the Coefficient of Determination

\begin{tabular}{cc}
\hline Coefficient interval & Influence level \\
\hline $0 \%-19.9 \%$ & Very weak \\
$20 \%-39.9 \%$ & Weak \\
$40 \%-59.9 \%$ & Currently \\
$60 \%-79.9 \%$ & Strong \\
$80 \%-100 \%$ & Very strong \\
\hline Source: Sugiyono (2017: 184$)$ &
\end{tabular}


Table 7 coefficient of multiple determination

\begin{tabular}{lcccc}
\hline $\begin{array}{l}\text { Mod } \\
\text { el }\end{array}$ & $\mathrm{R}$ & R Square & Adjusted R Square & Std. Error of the Estimate \\
\hline 1 & $.997 \mathrm{a}$ & .993 & .993 & \\
a. Predictors: (Constant), LN_GIRO, LN_TABUNGAN, LN_DEPOSITO & .14420 \\
b. Dependent Variable: LN_CREDIT & & \\
\hline
\end{tabular}

Dataprocessed SPSS 16.0

$$
\begin{aligned}
\mathrm{Kd} & =r^{2} \times 100 \% \\
& =0.993 \times 100 \% \\
& =99.3 \%
\end{aligned}
$$

Based on table 7 above, the value ( $R$ square) between the variables of Current Accounts, Savings, and Time Deposits on Credit Distribution is 0.993 or this result shows that $99.3 \%$ of Credit Distribution gains are influenced by Current Accounts, Savings, and Time Deposits. While the remaining $0.7 \%$ is influenced by other variables not examined in this study. Thus it can be concluded that between the variables of Current Accounts (X1), Savings (X2), and Time Deposits (X3) on Credit Distribution (Y). has a very strong influence based on the interpretation table 3.10 page 64 the coefficient of determination of $99.3 \%$ is in the range of $80 \%-100 \%$ with a very strong level of influence.

\section{g) T Test (Partial)}

The t-test is used to prove whether the variables of Current Accounts, Savings, and Time Deposits partially have an effect on Credit Distribution. To test whether the specified hypothesis is accepted or rejected. If the significance value produced by the $t$ test $(p<0.05)$ it can be concluded that partially the independent variable has a significant effect on the dependent variable.

Table 8 partial t test results

\begin{tabular}{lccccc}
\hline \multicolumn{7}{c}{ Coefficientsa } \\
\multicolumn{7}{c}{$\begin{array}{c}\text { Unstandardized } \\
\text { Coefficients }\end{array}$} & $\begin{array}{c}\text { Standardize } \\
\text { d } \\
\text { Coefficients } \\
\text { Model }\end{array}$ & B & Std. Error & Beta & T & Sig. \\
\hline 1 (Constant) & $-1,247$ & .406 & & -3.071 & .004 \\
LN_GIRO & .221 & .059 & .200 & 3,731 & .001 \\
LN_SAVINGS & .509 & .074 & .374 & 6.891 & .000 \\
LN_DEPOSIT & .407 & .048 & .436 & 8,526 & .000 \\
a. Dependent Variable: LN_CREDIT & & & & \\
\hline Source: Data processed by SPSS 16.0 & & & & &
\end{tabular}

Based on the results of the calculation of the output in table 8 above, it can be seen that the value of tcount shows a number of:

a. 3,731 for the Giro variable (X1).

b. 6.891 for the Savings variable (X2).

c. 8,526 for the Deposit variable (X3).

1. First Hypothesis (H1) 
The steps in testing the hypothesis are as follows:

a. Statistical hypothesis:

Ho: $p=0$

$\mathrm{Ha}: \mathrm{p} 0$

The hypothesis in the form of a sentence:

Ho : $p=0:$ There is no Influence of Current Accounts with Credit Distribution at PT.

National Private Commercial Banks listed on the Indonesia Stock Exchange for the 2014-2019 period.

$\mathrm{Ha}:$ p 0 : There is an Influence of Current Accounts with Credit Distribution at PT.

National Private Commercial Banks listed on the Indonesia Stock Exchange for the 2014-2019 period.

b. Determine the decision rule:

a) If the value of tcount > ttable, then Ho is rejected and $\mathrm{H} 1$ is accepted, meaning that it is significant.

b) If the value of tcount $<$ ttable, then Ho is accepted and $\mathrm{H} 1$ is rejected, meaning that it is not significant.

c. Procedure for searching tables and criteria:

a) Significant level $(\alpha=0.05)$.

b) $\mathrm{df}$ (degree of freedom) $=\mathrm{nk}(42-4=38)$ then the table value is 2.024

Based on table 8 the t-test value obtained partially the effect of the current account variable on credit distribution is the current account, it is obtained tcount $>$ ttable $(3,731>$ 2.024) with a significant level of $0.001<0.05$, it means that Ho is rejected and $\mathrm{H} 1$ is accepted, in other words that there is an influence between Current Accounts on Credit Distribution. To find out where the effect is, it can be seen from the following curve:

Ho rejection area

Area Ho's rejection

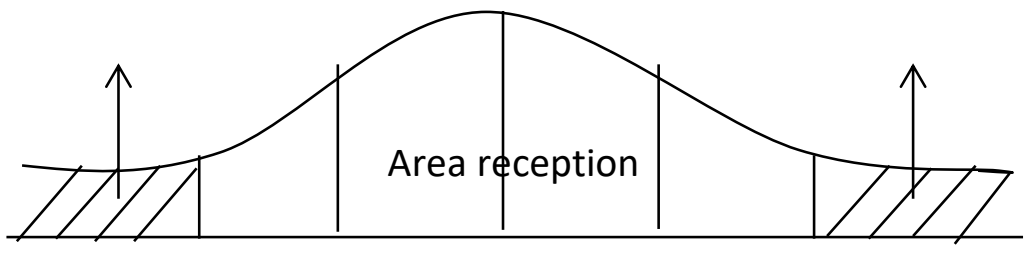

$-2.024-3.731$

3.731

2.024

Figure 3. T-test curve of Demand Deposits on Credit Distribution

From Figure 3 above shows the value of tcount is greater than ttable $(3,731>2,024)$ so that $\mathrm{Ho}$ is rejected and $\mathrm{H} 1$ is accepted. "There is an influence between Current Accounts on Credit Distribution".

2. Second hypothesis $(\mathrm{H} 2)$

The steps in testing the hypothesis are as follows:

a. Statistical hypothesis:

Ho $: p=0$

$\mathrm{Ha}: \mathrm{p} 0$ 
The hypothesis in the form of a sentence:

Ho : $p=:$ There is no Effect of Savings with Credit Distribution at PT. National Private Commercial Banks listed on the Indonesia Stock Exchange for the 2014-2019 period.

$\mathrm{Ha}: \mathrm{p}=:$ There is an Influence of Savings with Credit Distribution at PT. National Private Commercial Banks listed on the Indonesia Stock Exchange for the 2014-2019 period.

b. Determine the decision rule:

a) If the value of tcount $>$ ttable, then $\mathrm{Ho}$ is rejected and $\mathrm{H} 2$ is accepted, meaning that it is significant.

b) If the value of tcount $<$ ttable, then $\mathrm{Ho}$ is accepted and $\mathrm{H} 2$ is rejected, meaning that it is not significant.

c. Procedure for searching tables and criteria:

a) Significant level $(\alpha=0.05)$.

b) $\mathrm{df}$ (degree of freedom) $=\mathrm{nk}(42-4=38)$ then the ttable value is 2.024

II Based on table 8 the t-test value obtained partially the effect of the savings variable on lending is savings, it is obtained tcount $>$ ttable $(6.891>2.024)$ with a significant level $(0.000<0.05)$ it means that $\mathrm{Ho}$ is rejected and $\mathrm{H} 2$ is accepted, in other words there is an influence between savings on credit distribution. To find out where the effect is, it can be seen from the following curve:

Ho rejection area Area Ho's rejection

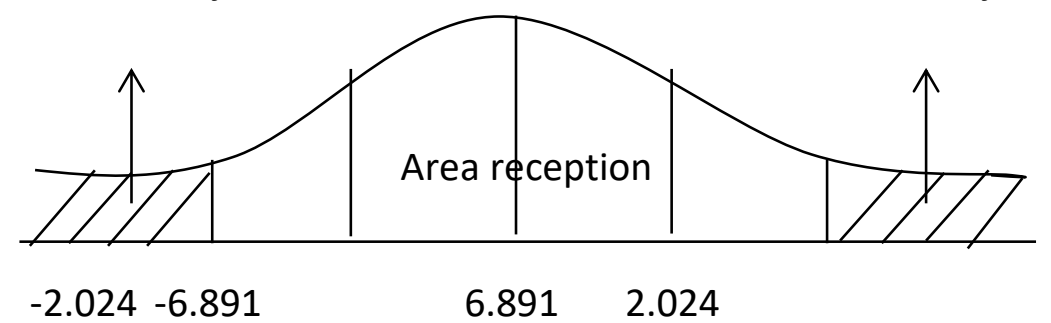

Figure 4. T test curve of Savings to Credit Distribution

From Figure 4 above shows the value of tcount is greater than ttable $(6,891>2,024)$ so that $\mathrm{Ho}$ is rejected and $\mathrm{H} 2$ is accepted. "There is an influence between Savings on Credit Distribution".

3. Third hypothesis (H3)

Step-The steps in testing the hypothesis are as follows:

a. Statistical hypothesis:

Ho $: p=0$

$\mathrm{Ha}: \mathrm{p} 0$

The hypothesis in the form of a sentence:

Ho: $p=:$ There is no influence of Deposit with Credit Distribution at PT. National Private Commercial Banks listed on the Indonesia Stock Exchange for the 2014-2019 period. 
Ha $: p=:$ There is an effect of Deposit with Credit Distribution at PT. National Private Commercial Banks listed on the Indonesia Stock Exchange for the 2014-2019 period.

b. Determine the decision rule:

a) If the value of tcount > ttable, then $\mathrm{Ho}$ is rejected and $\mathrm{H} 3$ is accepted, meaning that it is significant.

b) If the value of tcount < ttable, then Ho is accepted and H3 is rejected, meaning that it is not significant.

c. Procedure for searching tables and criteria:

a) Significant level $(\alpha=0.05)$.

b) $d f($ degree of freedom $)=n k(42-4=38)$ then the table value is 2,024 .

Based on table 8 the t-test value obtained partially the effect of the Deposit variable on lending is deposits obtained tcount $>$ ttable $(8,526>2,024)$ with a significant level $(0.000<0.05)$ it means that $\mathrm{Ho}$ is rejected and $\mathrm{H} 3$ is accepted, in other words there is an influence between Deposits on Credit Distribution. To find out where the effect is, it can be seen from the following curve:

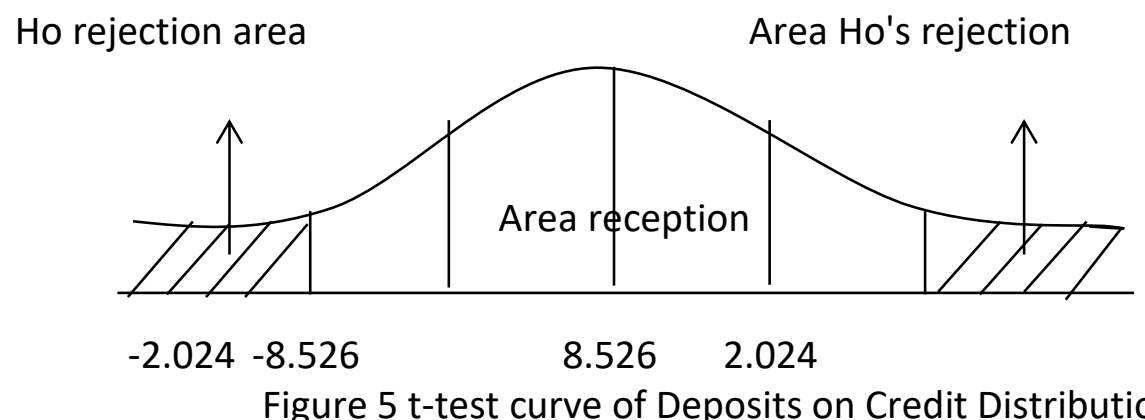

From Figure 5 above, the value of tcount is greater than ttable $(8,526>2,024)$ so that $\mathrm{Ho}$ is rejected and $\mathrm{H} 3$ is accepted. "There is an influence between Deposits on Credit Distribution".

\section{h) F Test (Simultaneous)}

The $\mathrm{F}$ test aims to determine whether there is a simultaneous (simultaneous) effect on Current Accounts, Savings and Deposits on Credit Distribution, to test whether the specified hypothesis is accepted or rejected. The steps in hypothesis testing are as follows:

1. Third hypothesis $(\mathrm{H} 4)$

Step-The steps in testing the hypothesis are as follows:

a. Statistical hypothesis:

Ho $: p=0$

$\mathrm{Ha}: \mathrm{p} 0$

The hypothesis in the form of a sentence:

Ho $: p=:$ There is no influence of Current Accounts, Savings, and Time Deposits with Credit Distribution at PT. National Private Commercial Banks listed on the Indonesia Stock Exchange for the 2014-2019 period. 
Ha : $p=:$ There is an Influence of Current Accounts, Savings, and Time Deposits with Credit Distribution at PT. National Private Commercial Banks listed on the Indonesia Stock Exchange for the 2014-2019 period.

b. Determine the decision rule:

a) If the value of fcount $>$ ftable, then $\mathrm{Ho}$ is rejected and $\mathrm{Ha}$ is accepted, meaning that it is significant.

b) If the value of fcount < ftable, then Ho is accepted and $\mathrm{Ha}$ is rejected, meaning that it is not significant.

c. Procedure for searching tables and criteria:

a) Significant level $(\alpha=0.05)$.

b) $\mathrm{df1}=(\mathrm{k}-1)$ and $\mathrm{df2}(\mathrm{nk})=(4-1) ;(42-4)=3 ; 38$ then the ftable value is 2.85 .

Table 9 Simultaneous test ( $\mathrm{F}$ test)

\begin{tabular}{|c|c|c|c|c|c|c|}
\hline \multicolumn{7}{|c|}{ ANOVAb } \\
\hline \multicolumn{2}{|c|}{ Model } & $\begin{array}{l}\text { Sum of } \\
\text { Squares }\end{array}$ & df & Mean Square & $\mathrm{F}$ & Sig. \\
\hline \multirow[t]{3}{*}{1} & Regression & 116,507 & 3 & 38,836 & $\begin{array}{r}1867,55 \\
8\end{array}$ & $.000 \mathrm{a}$ \\
\hline & Residual & .790 & 38 & .021 & & \\
\hline & Total & 117,297 & 41 & & & \\
\hline \multicolumn{7}{|c|}{ a. Predictors: (Constant), LN_GIRO, LN_TABUNGAN, LN_DEPOSITO } \\
\hline \multicolumn{7}{|c|}{ b. Dependent Variable: LN_CREDIT } \\
\hline
\end{tabular}

Source: Data processed by SPSS Statistics 0.16.

Based on the results of the SPSS output in table 4.19 above, it can be seen that the value obtained is fcount $>$ ftable $(1867,558>2.83)$ with a significant level $(0.000<0.05)$ which means Ho is rejected and $\mathrm{H} 4$ is accepted, in other words that simultaneously (simultaneous) current accounts, savings, and time deposits have an effect on lending.

\section{The Effect of Current Accounts (X1) on Credit Distribution (Y)}

Based on statistical analysis in this study, it can be seen that the results of the $t$ test (partial) stated that the value of tcount $>$ ttable $(3,731>2,024)$ then Ho was rejected and $\mathrm{H} 1$ was accepted with a significance level of $(0.001<0.05)$ so it can be concluded that there is an effect of Current Accounts on Credit Distribution .This is also supported by the results of the determination test of the Demand Deposit (X1) variable on Credit Distribution (Y) of 0.953 or equal to $95.3 \%$ which is in the range of $80 \%-100 \%$ with a very strong level of influence. This shows that $95.3 \%$ of the credit distribution variables can be explained by variations in the current account variable, while the remaining $4.7 \%$ is influenced by other variables not examined in this study. This is also supported by the theory of third party funds (Giro, Savings, and Time Deposits) on the balance sheet which also shows that the main source of financing for credit is third party funds, namely Current Accounts, Savings, and Time Deposits and others. the greater the amount of credit issued. This is in line with the facts in this study that on average, current account deposits at National Private Commercial Banks reach Rp.IDR 174,904,311 in 2014-2019 and lending of IDR 1,588,529,589 to National Private Commercial Banks 2014-2019 which are listed on the Indonesia Stock Exchange, this shows that every 
increase in the average demand deposit in each year will increase lending (Yusuf, 2010), The amount of funds received by the bank can affect how much credit will be issued by the bank itself. This study is in line with previous research, which said that there was a positive influence of Current Accounts on Credit Distribution (Widiawati, 2018).

\section{Effect of Savings (X2) on Credit Distribution (Y)}

Based on statistical analysis in this study, it can be seen that the results of the t-test (partial) stating the value of tcount $>$ ttable $(6,891>2,024)$ then $\mathrm{Ho}$ is rejected and $\mathrm{H} 2$ is accepted with a significance level of $(0.000<0.05)$ so it can be concluded that there is an effect of Savings on Credit Distribution.This is also supported by the results of the determination test of the Savings variable (X2) on Credit Distribution (Y) of 0.968 or equal to $96.8 \%$ which is in the range of $80 \%-100 \%$ with a very strong level of influence. This shows that $96.8 \%$ of the Credit Distribution variables can be explained by variations in the Savings variable, while the remaining $3.2 \%$ is influenced by other variables not examined in this study. This is also supported by the theory of third party funds (Giro, Savings, and Time Deposits) on the balance sheet which also shows that the main source of financing for credit is third party funds, namely Current Accounts, Savings, and Time Deposits and others. the greater the amount of credit issued. This is in line with the facts in this study that on average the Savings deposit fund at National Private Commercial Banks reaches Rp. Rp. 117,514,015 in 2014-2019 and lending of Rp. 1,588,529,589 at National Private Commercial Banks for 2014-2019 which are listed on the Indonesia Stock Exchange. This shows that the average savings increase every year, in other words, it can be concluded that an increase in savings each year can affect the amount of credit that will be issued by the bank (Yusuf, 2010). This research is in line with previous research, which says that there is a positive effect of Savings on Credit Distribution (Sari, 2017).

\section{Effect of Deposits (X3) on Credit Distribution (Y)}

Based on the statistical analysis in this study, it can be seen that the results of the t-test (partial) stating the value of tcount $>$ ttable $(8,528>2,024)$ then Ho is rejected and $\mathrm{H} 3$ is accepted with a significance level of $(0.000<0.05)$ so it can be concluded that there is an effect of Deposits on Credit Distribution. This is also supported by the results of the determination test of the Deposit variable (X3) on Credit Distribution (Y) of 0.971 or equal to $97.1 \%$ which is in the range of $80 \%-100 \%$ with a very strong level of influence. This shows that $97.1 \%$ of the Credit Distribution variables can be explained by variations in the Time Deposit variable, while the remaining $2.9 \%$ is influenced by other variables not examined in this study. This is also supported by the theory of third party funds (Current Accounts, Savings, and Time Deposits), namely the funds collected by banks from the public turned out to be the largest and most reliable source of funds by banks, the more third party funds, namely Deposit funds, collected by a bank. the bank, the more funds that can be processed by the bank, namely in the form of lending. This is in line with the facts in this study that on average, the Deposit funds at National Private Commercial Banks reached Rp.Rp 1,540,487,840 in 2014-2019 and credit of Rp 1,588,529,589 in 2014-2019 National Private Commercial Banks listed on the Indonesia Stock Exchange (Dendawijaya, 2009). From the existing data, it can be seen that the average deposit increases every year, the increase in the average deposit affects the amount of credit that will be 
issued by the bank. This study is in line with previous research, which said that there was a positive effect of Deposits on Credit Distribution (Mukaromah, 2015).

\section{Effect of Current Accounts (X1), Savings (X2), and Time Deposits (X3) on Credit Distribution (Y)}

Based on the results of statistical analysis in this study, it can be seen that the results of the $\mathrm{F}$ test (simultaneous) the value of Fcount $>$ Ftable of $(1867,557>2.85)$ with a significance value of $0.000<0.05$, it can be concluded that $\mathrm{Ho}$ is rejected and $\mathrm{H} 4$ is accepted, meaning that there is an influence of the Current Account, Savings variable. , and Deposits together (simultaneously) for Credit Distribution at PT. National Private Commercial Bank for 2014-2019 Period.This is also supported by the results of the determination test of the variables of Demand Deposits (X1), Savings (X2), and Time Deposits (X3) to Credit Distribution (Y) simultaneously obtained R square of 0.993 or this result shows that $99.3 \%$ which is in the range $80 \%-100 \%$ with a very strong level of influence. This means that the remaining $0.7 \%$ is influenced by other variables not examined in this study. Thus, it can be concluded that the variables of Current Accounts (X1), Savings (X2), and Savings (X3) on Credit Distribution (Y) have a very strong level of influence. In this study, it is in accordance with previous findings, which say that Current Accounts, Savings, and Time Deposits simultaneously (simultaneously) affect Credit Distribution. This shows from the results of this study that Current Accounts, Savings, and Time Deposits together (simultaneously) have an effect on Credit Distribution at National Private Commercial Banks listed on the Indonesia Stock Exchange for the 2014-2019 Period (Andini, 2016).

\section{Conclusion}

Based on the results of research and hypothesis testing of this study, namely regarding the effect of Current Accounts, Savings and Time Deposits on Credit Distribution at PT. National Private Commercial Banks listed on the IDX for the period 2014-2019, the following conclusions can be drawn: The results of the t-test (partial) for the Giro variable on Credit Distribution (X1 to Y) using SPSS show tcount $>$ ttable $(3.713>2.024)$ then $\mathrm{HO}$ is rejected and $\mathrm{H} 1$ is accepted which meansCurrent accounts have an effect on credit distribution. This is also supported by the results of the partial determination test of the $X 1$ variable against $Y$ of 0.953 or equal to $95.3 \%$ whichis in the range of $80 \%$ - $100 \%$ with a very strong level of influence which means that there is an influence between Current Accounts on Credit Distribution at PT. National Private Commercial Banks listed on the IDX for the period 2014-2019. The results of the t-test (partial) for the Savings variable on Credit Distribution (X2 against $Y$ ) using SPSS show tcount $>$ ttable $(6,891>2,024)$ then $\mathrm{HO}$ is rejected and $\mathrm{H} 2$ is accepted which meansSavings have an effect on credit distribution. This is also supported by the results of the partial determination test of the $X 2$ variable against $Y$ of 0.968 or equal to $97 \%$ yangare in the range of $80 \%-100 \%$ with a very strong level of influence which means there is an influence between Savings on Credit Distribution at PT. National Private Commercial Banks listed on the IDX for the period 20142019. The results of the t-test (partial) for the Time Deposit variable on Credit Distribution (X3 against $\mathrm{Y})$ using SPSS show tcount $>$ ttable $(8,528>2,024)$ then $\mathrm{HO}$ is rejected and $\mathrm{H} 3$ is accepted which meansDeposits have an effect on credit distribution. This is also supported by the results of the partial determination test of the $X 1$ variable against $Y$ of 0.971 or equal to $97.1 \%$ whichis in the range of $80 \%$ - $100 \%$ with a very strong level of influence which means there is an influence between Deposits on Credit Distribution at PT. National Private Commercial Banks listed on the IDX for the period 20142019. Simultaneous test results of Current Accounts, Savings, and Time Deposits on Credit 
Distribution (X1, X2 and X3 against $Y$ ) using SPSS show Fcount > Ftable(1867,558 > 2.85)meaning that Current Accounts, Savings, and Time Deposits have a simultaneous (simultaneous) effect on Credit Distribution. This is also supported by the results of the determination test of the variables $\mathrm{X} 1, \mathrm{X} 2$ and $X 3$ against $Y$ simultaneously, the $R$. value is obtainedSquareof 0.993 or this result shows that $99.3 \%$ of those who arein the range of $80 \%-100 \%$ with a very strong level of influence which means that there is a simultaneous (simultaneous) influence between Current Accounts, Savings, and Time Deposits on Credit Distribution at PT. National Private Commercial Banks listed on the IDX for the period 2014-2019.

The number of fundraisers from the public of National Private Commercial Banks in the form of Demand Deposits, Savings and Time Deposits is very important to consider in predicting the distribution of credit that will be channeled by the Bank to the public, because based on the results of joint research (simultaneous) demand deposits, savings and deposits have an effect on credit distribution. , the higher the loan disbursement, the bank should be careful and pay attention to the $5 \mathrm{C}$ principle.

Based on the conclusions above, the authors convey some suggestions as follows: The banking sector needs to improve the quality of service to customers, especially customers who provide funds for savings such as demand deposits, savings and time deposits. This is necessary so that they will have more confidence in the national private commercial banks and will feel more comfortable in depositing their funds in national private commercial banks. Banking parties need to pay attention to third party funds collected from the public, especially deposits in lending, one way to increase deposits is to do this for example by providing attractive interest rates. National private public banking, should improve performance from year to year for the better so that people as demand deposits, savings and time deposits have the desire and trust to place their funds. Likewise with the level of NPL which describes the soundness of a bank. So that the national private commercial bank maintains a low level of NPL and pays attention to the feasibility level of debtors in lending so that non-performing loans do not occur.

\section{References}

A. Dzaluli and Yadi Yanuari, People's Economic Institutions (A) Introduction), (Jakarta:Rajawali Press, 2001 p. 53

Abdul Ghofur Ansori, Islamic Banking in Indonesia, 2009, Yogyakarta: Gadjah Mada University Press.

Agus Arijanto, Parents' Sins against Children in Financial Matters, 2010, Jakarta: PT. Elex Media Computerindo.

Andrianto, Bank Management, 2017, Surabaya : UM Press.

Dendawijaya, "Banking Management Second Edition", 2009, Jakarta: Ghalia Indonesia.

Eryadi, IPSL(Complete Digest of Social Knowledge) ,2007, Jakarta : PT.Kawan References.

Gunarto Suhardi, Banking Business in Legal Perspective, 2003, Yogyakarta: Kanisius.

Irma Aprianti, 2016," Analysis of the Effect of Total Savings, Current Accounts and Time Deposits against Amount Credit and Number of Bank Indonesia Certificates"UIN

Ismail, Bank Accounting (Theory and Application in Rupiah), 2010, Jakarta : Prenada Media Group.

Ismail, Banking Management, 2010, Jakarta : Pranda Media Group.

Iswi, Haryani, Restructuring and Elimination of Bad Credit, 2010, Jakarta: Gramedia. 
Jusuf, 2010, Capital Markets and as a means of Financing as an Investment, Bandung: PT. Alumni.

Karina, SPSS STIE Bina Bangsa Banten Application Module, 2013 Attack: LPPM STIE Bina NationBanten

Kasmir, Banks and Other Financial Institutions, 2014, Jakarta : PT. Press Eagle.

Lailatul Mukaromah, "The Influence of Savings, Deposits, and Credits on Profitability of PT. BPR Topati Kencana Denpasar", 2015, E-Journal of Unud Management, Vol. 4, No. 8.

M.Taufik, The Effect of Deposit Growth on Credit with Imflas as a Variableas moderation at Commercial Banks in Indonesia,2015, Semarang: STIE Dharma Putra, Page 4

N.Napoliwa, Daniel S. Kusuma, Banking Accounting: Accounting for Internal Bank Transactions Rupiah Currency,2018, Jakarta: Indonesian Bankers Institute.

Ni Putu Kamanila, et al, 2017, "Current Accounts, Savings, Time Deposits, and Working Capital Loans against Profitability of Banking Companies listed on the Indonesia Stock Exchange in 20102014",(vols: 7 No: 1 ), Ganesh University of Education.

Putri Andini, "The Influence of Third Party Funds, BI Rate, and BOPO on Banking Credit Distribution", 2016, Telkom University.

Putri Rosyida, Analysis of the Effect of Third Party Funds (DPK), Capital Adequacy Ratio(CAR), Non Performing Loans (NPL), and Return On Assets (ROA) on Credit Distribution Banking, 2014 Semarang : Ponegoro University.

Rachmadi Usman, Legal Aspects of Banking in Indonesia, 2003, Jakarta : PT.Gramedia Main Library

Sugiyono, quantitative, qualitative, and R\&D research methods, 2017, Bandung: Alfabeta

Suyatmo, Indonesian Credit Systems and Procedures, 2008, Jakarta : Second Edition, Rineka . Publisher Create.

Taswan, Banking Management (Concepts, Techniques and Applications) ,2010, Yogyakarta : Edition Second, UPP STIM YKPN.

Viethzal rivai, Bank and Financial Institute, 2007, Jakarta: RajaGrafindo Persada

Yusuf Ali Furtasan et al, Guidelines for Writing Scripts and Scientific Journals, Serang: Bina university Nation 2019/2020, P.49 